\title{
PERBEDAAN PENGARUH METODE LATIHAN DAN KEMAMPUAN GERAK (MOTOR ABILITY) TERHADAP PENINGKATAN KETERAMPILAN MENEMBAK (JUMP SHOOT) BOLA BASKET
}

\author{
Gede Eka Budi Darmawan \\ Jurusan Pendidikan Kepelatihan Olahraga, Fakultas Olahraga dan Kesehatan \\ Universitas Pendidikan Ganesha \\ Singaraja, Indonesia \\ e-mail: dgedeekabudi@yahoo.co.id
}

\begin{abstract}
Abstrak
Penelitian ini bertujuan mengetahui interaksi antara metode latihan (distributed practise dan massed practise) dan tingkat motor ability (kemampuan gerak) terhadap peningkatan keterampilan jump shoot bola basket. Penelitian menggunakan metode eksperimen dengan rancangan faktorial $2 \times 2$. Sampel penelitian berjumlah 36 orang. Teknik pengambilan data motor ability dengan menggunakan barrow motor ability test dan data keterampilan jump shoot bola basket menggunakan speed spot shooting test. Teknik analisis data menggunakan analisis varian (anava) rancangan 2 jalur dan pengujian hipotesis dilakukan dengan uji $F$ pada taraf signifikansi $\alpha=0,05$. Hasil penelitian dapat disimpulkan sebagai berikut terdapat pengaruh interaksi yang signifikan antara perbedaan metode latihan dan motor ability terhadap peningkatan keterampilan jump shoot bola basket yaitu: 1) Mahasiswa yang memiliki motor ability tinggi lebih cocok jika mendapat latihan distributed practise, dan 2) Mahasiswa yang memiliki motor ability rendah lebih cocok jika mendapat latihan massed practise.
\end{abstract}

Kata kunci: metode latihan, motor ability, keterampilan jump shoot.

\begin{abstract}
This study is aimed to identify an interaction between practice method and the level of motor ability toward the basketball jump shoot skill improvement. This study is an experimental research with $2 \times 2$ factorial designs. The sample was 36 students. Motor ability data was collected by using barrow motor ability test. Meanwhile, the basket ball jump shoot skill data was collected by using speed spot shooting test. Those data were analyzed by using 2 ways anava and the hypothesis was tested by using $F$ test with $a=0.05$ as the level of significance. It was found that there was a significant effect of interaction between practice method and motor ability toward basketball jump shoot improvement. The conclusion is 1) Students with higher motor ability are suitable to be involved in a distributed practice 2) Students with lower motor ability are more suitable to be involved in the massed practice.
\end{abstract}

Key words: practice method, motor ability, jump shoot skill 


\section{PENDAHULUAN}

Bola basket adalah salah satu jenis permainan olahraga yang mengunakan bola besar. Mata kuliah Teori dan Praktek (TP) Kepelatihan Bola Basket merupakan salah satu mata kuliah keahlian berkarya (MKB) yang bertujuan menghasilkan tenaga ahli dengan kekaryaan berdasarkan dasar ilmu kepelatihan bola basket dan keterampilan yang dikuasai serta wajib dikuasi oleh mahasiswa Jurusan Pendidikan Kepelatihan Olahraga (PKO) Fakultas Olahraga dan Kesehatan (FOK) UNDIKSHA. Pada umumnya mahasiswa PKO berasal dari daerah-daerah yang tersebar di sembilan kabupaten yang ada di Bali dan sebagian kecil berasal dari luar Bali. Setelah tamat, mereka tidak hanya diharapkan menjadi tenaga yang profesional di bidang kepelatihan olahraga, tetapi mereka juga diharapkan menjadi pendidik utama dalam mengajar atau melatih salah satu mata pelajaran yang ada di sekolah masingmasing.

Akan tetapi penguasaan keterampilan teknik dasar bola basket khususnya teknik menembak (shooting) yang dikuasai oleh mahasiswa selama dalam proses latihan atau pembelajaran dan setelah lulus mata kuliah ini belum menunjukkan kemampuan dan keterampilan yang diharapkan di masyarakat. Hal ini disebabkan oleh jumlah satuan kredit semester yang relatif kecil (2 sks), waktu latihan yang terbatas, fasililas yang kurang memadai, metode latihan atau pengajaran yang kurang efektif, kemampuan beradaptasi terhadap penguasaan keterampilan atau kemampuan gerak (motor ability) rendah, faktor lingkungan belajar yang kurang mendukung serta faktor bakat, karena orang yang mempunyai bakat akan lebih mudah dan lebih cepat mengerjakan atau mempelajari suatu permainan.

Seorang pelatih atau guru perlu mempelajari, memahami, dan mampu menerapkan berbagai strategi, dan metode latihan atau pendekatan pembelajaran pada bidang studi yang diampunya. Strategi merupakan perencanaan yang berisi tentang rangkainan kegiatan yang didesain untuk mencapai tujuan latihan atau pembelajaran tertentu. Metode merupakan implementasi dari rencana yang telah disusun dalam kegiatan latihan agar tujuan tercapai. Dalam proses latihan diperlukan adanya metode latihan untuk membantu pencapaian tujuan latihan, semakin tepat metode latihan maka makin efektif dan tujuan latihan akan tercapai.

Fenomena yang berkembang saat ini, pelatih atau guru belum memahami tentang pemanfaatan waktu latihan yang tepat, sehingga muncul pertanyaan di kalangan pelatih atau guru tentang berapa lama suatu latihan harus berlangsung, apakah latihan harus didistribusikan atau digabungkan, kapan periode istirahat harus diberikan. Untuk menjawab pertanyaan ini diperlukan metode latihan yang tepat dan pemanfaatan waktu latihan yang tepat atau baik akan meningkatkan efisiensi untuk pencapaian tujuan yang diharapkan. Oleh karena itu pemanfaatan waktu harus diatur dengan baik sehingga waktu latihan yang digunakan untuk praktik tidak mengalami kelelahan. Ada dua metode latihan yang mempertimbangkan waktu latihan (aktif) dan waktu istirahat yaitu latihan Distributed Practise (Praktik Terdistribusi) dan latihan Massed Practise (Praktik Padat). Dalam latihan Distributed Practise (Praktik Terdistribusi) atlet atau siswa mempraktikkan gerakan diselang-selingi dengan waktu istirahat dan latihan Massed Practise (Praktik Padat) atlet mempraktikan gerakan terus-menerus tanpa istirahat sampai waktu habis (Lankor, 2007:98).

Di samping metode latihan pelatih atau guru memperhatikan karakter atlet atau siswa termasuk kemampuan gerak, karena kemampuan gerak dasar juga berpengaruh terhadap keterampilan menebak (shtooting) bola basket. Setiap individu mempunyai kemampuan gerak yang berbeda-beda, terjadinya perbedaan kemampuan gerak antara atlet atau siswa karena kondisi kualitas fisik yang berbeda, baik kondisi 
secara internal maupun eksternal. Kemampuan gerak (motor ability) salah satu kondisi internal yang membedakan setiap individu dalam mengembangkan suatu keterampilan gerak, dapat dipandang sebagai landasan keberhasilan masa yang akan datang di dalam melakukan keterampilan gerak. Perbedaan kemampuan gerak memiliki implikasi terhadap proses latihan. Ketepatan dan penugasan keterampilan olahraga dipengaruhi kemampuan gerak, sehingga tinggi rendahnya kemampuan gerak yang dimiliki atlet menentukan keterampilan menebak (shooting) bola basket. Perbedaaan kemampuan gerak atlet akan menjadi bahan pertimbangan yang penting ketika pelatih atau guru memilih atau menentukan metode latihan yang sesuai dengan karakter dari masing-masing atlet atau siswa.

Ada beberapa hal yang harus diperhatikan dalam meningkatkan keterampilan menembak (shooting) bola basket, salah satu diantaranya dengan mengunakan metode latihan yang tepat dan hendaknya digabungkan dengan kemampuan gerak (motor ability) sehingga hasil yang diperoleh akan maksimal. Sehubungan dengan hal tersebut di atas maka perlu dilakukan penelitian yang mengkaji mengenai "Perbedaan Pengaruh Metode Latihan dan Kemampuan Gerak (Motor Ability) Terhadap Peningkatan Keterampilan Menembak (Jump Shoot) Bola Basket".

Rumusan masalah dalam penelitian adalah: 1) Apakah ada perbedaan pengaruh antara metode latihan distributed practise dan latihan massed practise terhadap peningkatan keterampilan jump shoot bola basket ? 2) Apakah ada perbedaan peningkatan keterampilan jump shoot bola basket antara yang memiliki tingkat motor ability tinggi dan motor ability rendah ? 3) Apakah ada pengaruh interaksi antara metode latihan dan tingkat motor ability terhadap peningkatan keterampilan jump shoot bola basket?
Adapun tujuan dalam penelitian ini adalah untuk mengetahui : 1) Perbedaan pengaruh metode latihan distributed practise dan latihan Massed practise terhadap peningkatan keterampilan jump shoot bola basket, 2) Perbedaan peningkatan keterampilan jump shoot bola basket antara yang memiliki tingkat motor ability tinggi dan motor ability rendah, 3) Interaksi antara metode latihan dan tingkat motor ability terhadap peningkatan keterampilan jump shoot bola basket.

\section{METODE}

Jenis penelitian ini adalah eksperimen lapangan, ini didasarkan pada variabel serta tujuan yang ingin dicapai dalam penelitian. Kerlinger (2002:645) menyatakan bahwa eksperimen lapangan adalah kajian dalam suatu nyata (realitas), dengan memanipulasi satu variable bebas atau lebih dalam kondisi yang dikontrol dengan cermat oleh pembuat eksperimen sejauh yang dimungkinkan oleh situasinya. Desain yang dipergunakan dalam penelitian ini adalah faktorial 2x2 (Sudjana, 2002:154).

Teknik pengumpulan data dalam penelitian ini adalah dengan menggunakan tes dan pengukuran beberapa variabel adalah sebagai berikut: 1) Data tingkat motor ability mahasiswa yang diperlukan dikumpulkan dengan menggunakan dengan Barrow Motor Ability Test, yang terdiri dari 6 item tes (Jonson \& Nelson, 1986 : 383), yaitu: a) Standing broad jump, b) Soft ball throw, c) Zig-zag run, d) Wall pass, e) Medicine ball-put, f) The 60 yard dash. 2) Data keterampilan jump shoot bola basket yang digunakan adalah yaitu Speed Spot Shooting test (Kirkendall, 1987:221

Teknik analisis data yang digunakan untuk pengujian hipotesis adalah analisis varian (Anava) rancangan 2 jalur. Pengujian hipotesis dilakukan dengan taraf signifikansi $\alpha=0,05$ dan jika $F_{0}$-nya signifikan analisis dilanjutkan dengan uji rentang NewmanKeuls (Sudjana, 2005:36). Untuk memenuhi asumsi dalam teknik Anava, maka dilakukan Uji Normalitas (Uji Lilliefors) dan Uji 
Homogenitas Varians (Uji Bartlet) (Sudjana, 2005:261-264).

\section{HASIL DAN PEMBAHASAN}

Berdasarkan hasil analisis data di atas dapat dilakukan pengujian hipotesis sebagai berikut: 1) Pengujian Hipotesis I : Dari hasil penelitian menunjukkan bahwa latihan distributed practise memiliki peningkatan yang berbeda dengan latihan massed practise. Hal ini dibuktikan dari nilai $F_{\text {hitung }}=6.7640>F_{\text {tabel }}=4.11$. Dengan demikian $\mathrm{H}_{0}$ ditolak. Yang berarti bahwa latihan distributed practice memiliki peningkatan yang berbeda dengan latihan massed practise dapat diterima kebenarannya. Dari analisis lanjutan diperoleh bahwa ternyata latihan distributed practise memiliki peningkatan yang lebih baik daripada latihan massed practise, dengan rata-rata peningkatan masingmasing yaitu 2.150 point dan 1.600 point. 2) Pengujian Hipotesis II : Dari hasil penelitian menunjukkan bahwa mahasiswa yang memiliki motor ability tinggi memiliki peningkatan hasil keterampilan jump shoot yang berbeda dengan mahasiswa yang memiliki motor ability rendah. Hal ini dibuktikan dari nilai $F_{\text {hitung }}=4.5280>F_{\text {tabel }}=$ 4.11. Dengan demikian hipotesa nol $\left(\mathrm{H}_{0}\right)$ ditolak. Yang berarti bahwa mahasiswa yang memiliki motor ability tinggi memiliki peningkatan hasil keterampilan jump shoot yang berbeda dengan mahasiswa yang memiliki motor ability rendah dapat diterima kebenarannya. Dari analisis lanjutan diperoleh bahwa ternyata mahasiswa yang memiliki motor ability tinggi memiliki peningkatan hasil keterampilan jump shoot yang lebih baik dari pada mahasiswa yang memiliki motor ability, dengan rata-rata peningkatan masing-masing yaitu 2.100 point dan 1.650 point. 3) Pengujian Hipotesis III : Dari hasil penelitian menunjukkan bahwa interaksi antara metode latihan (distributed practice dan massed practice) dan tingkat motor ability mahasiswa sangat bermakna. Karena $F_{\text {hitung }}$ $=16.1553>F_{\text {tabel }}=4.11$. Dengan demikian
Ho ditolak. Yang berarti terdapat interaksi yang signifikan antara metode latihan distributed practice dan lantihan massed practice dengan motor ability.

Pembahasan hasil penelitian ini memberikan penafsiran yang lebih lanjut mengenai hasil-hasil analisis data yang telah dikemukakan. Berdasarkan pengujian hipotesis menghasilkan dua kelompok kesimpulan analisis yaitu: (a) ada perbedaan pengaruh yang bermakna antara faktor-faktor utama penelitian (b) ada interaksi yang bermakna antara faktor-faktor utama dalam bentuk interaksi dua faktor. Kelompok kesimpulan analisis tersebut dapat dipaparkan lebih lanjut sebagai berikut: 1) Perbedaan Pengaruh Antara Metode Latihan Distributed Practise dan Latihan Massed Practise Terhadap Peningkatan Keterampilan Jump Shoot Bola Basket. Berdasarkan pengujian hipotesis pertama ternyata ada perbedaan pengaruh yang nyata antara kelompok mahasiswa yang mendapatkan latihan distributed practise dan kelompok mahasiswa yang mendapatkan latihan massed practise terhadap peningkatan keterampilan jump shoot. Pada kelompok mahasiswa yang mendapat latihan distributed practise mempunyai peningkatan keterampilan jump shoot yang lebih baik dibandingkan dengan kelompok mahasiswa yang mendapat latihan massed practise. Pada latihan massed practise, waktu recovery kurang sempurna, sehingga kualitas kecepatan gerakan tiap ulangannya tidak dapat dipertahankan secara sempurna sehingga mahasiswa mengalami kelelahan dan tidak fokus terhadap gerakan jump shoot. Latihan distributed practise lebih memberikan kesempatan mahasiswa untuk melakukan recovery sehingga lebih siap melakukan aktivitas dengan gerakan maksimal dengan baik. Dengan istirahat yang cukup maka mahasiswa dapat mengoreksi gerakannya, dan pada gerakan berikutnya jadi lebih baik dan kualitas kecepatan gerakan dapat dipertahankan sehingga peningkatan keterampilan jump shoot lebih signifikan. 2) 
Perbedaan Peningkatan Keterampilan Jump Shoot Antara yang Memiliki Tingkat Motor Ability Tinggi dan Rendah. Berdasarkan pengujian hipotesis ke dua ternyata ada perbedaan peningkatan yang nyata antara kelompok mahasiswa dengan motor ability tinggi dan rendah terhadap peningkatan keterampilan jump shoot. Pada kelompok mahasiswa dengan motor ability tinggi mempunyai peningkatan keterampilan jump shoot lebih tinggi dibanding kelompok mahasiswa dengan motor ability rendah. Pada kelompok mahasiswa motor ability tinggi memiliki potensi keterampilan jump shoot yang lebih tinggi daripada mahasiswa yang memiliki motor ability rendah. Motor ability atau kemampuan gerak merupakan modal yang mendasari dari gerak dalam pembentukan keterampilan dasar jump shoot yang dilakukan seseorang. Motor ability yang baik atau tinggi menunjang kesiapan mahasiswa untuk melakukan gerakan atau keterampilan jump shoot, dan dapat mempercepat proses penguasaan keterampilan gerak yang dilatih atau dipelajari. Mahasiswa yang memiliki motor ability tinggi memiliki kemampuan untuk beradaptasi terhadap latihan keterampilan jump shoot yang lebih baik dari pada mahasiswa yang memiliki motor ability rendah. 3) Interaksi Antara Metode Latihan dan Motor Ability Terhadap Peningkatan Keterampilan Jump Shoot. Berdasarkan hasil penelitian yang dicapai, ternyata mahasiswa yang memiliki motor ability tinggi lebih efekif atau baik dengan metode latihan distributed practise terhadap peningkatan hasil keterampilan jump shoot. Sedangkan mahasiswa yang memiliki motor ability rendah akan lebih efektif atau baik dengan latihan massed practise terhadap peningkatan keterampilan jump shoot. Keefektifan penggunaan metode latihan dipengaruhi oleh tinggi rendahnya motor ability yang dimiliki mahasiswa.

\section{SIMPULAN DAN SARAN}

Berdasarkan hasil penelitian dan hasil analisis data yang telah dilakukan, dapat diperoleh kesimpulan sebagai berikut: 1) Ada perbedaan pengaruh yang signifikan antara metode latihan distributed practise dan latihan massed practise terhadap peningkatkan keterampilan jump shoot. Pengaruh latihan distributed practise lebih baik daripada latihan massed practise terhadap peningkatan keterampilan jump shoot. 2) Ada perbedaan pengaruh yang signifikan antara motor ability tinggi dengan motor ability rendah terhadap peningkatan keterampilan jump shoot. Peningkatan keterampilan jump shoot pada mahasiswa yang memiliki motor ability tinggi lebih baik dari pada yang memiliki motor ability rendah. 3)Terdapat pengaruh interaksi yang signifikan antara perbedaan metode latihan dan motor ability terhadap peningkatan keterampilan jump shoot: a) Mahasiswa yang memiliki motor ability tinggi lebih cocok jika mendapat latihan distributed practise, b) Mahasiswa yang memiliki motor ability rendah lebih cocok jika mendapat latihan massed practise.

Berdasarkan hasil penelitian ini maka kepada pengajar dan pelatih diberikan saran-saran sebagai berikut: 1) Pelatih, guru, pembina olahraga khususnya bola basket disarankan merancang program latihan atau materi latihan secara terprogram dengan memperhatikan karakteristik dan motor ability atlet. Latihan distributed practise dan latihan massed practise yang diberikan harus memperhatikan tingkat motor ability atlet, sehingga dapat meningkatkan keterampilan jump shoot bola basket. 2) Untuk peneliti selajutnya selanjutnya yang berminat mengkaji pengaruh metode latihan dan motor ability terhadap peningkatan keterampilan jump shoot, sebaiknya menggunakan sampel yang lebih banyak tidak hanya pada tingkat mahasiswa, tetapi juga di tingkat SMA/SMK atau klub-klub dengan berbagai kelompok usia sehingga pengaruh metode latihan dapat diterapkan sesuai usia atlet. 


\section{DAFTAR PUSTAKA}

Bompa, O. Tudor. 1994. Theory and Methodology of training, Dubuque, lowa: Hunt Publishing Company.

Cratty. B.J. 1986. Perceptual Motor Development in Infants and Children. $3^{\text {rd }}$ ed. Englewood Cliffs. N.j: Prentice-Hall.

Foss, M.L. \& Keteyian, S.J. 1998. Physiological Basic for Exercise and Sport, New York: McGraw-Hill Companies, Inc.

Fox, E.L.1984. Sport Physiology. Saunders College Publishing

Hall Wissel. 1998. Bola Basket. Jakarta : PT. Raja Grafindo Persada.

Harsono, 1988. Coaching dan Aspekaspekpsikologis dalam coaching. Jakarta: Derjendikti.

Johnson, Barry L. and Jack K. Nelson. 1986. Pratical Measurement For Evaluation in Physical Education $4^{\text {nd }}$ ed. Macmillan Publishing Company.

Kerlinger, Fred N. 2002. Asas-asas Penelitian Behavioral (Edisi terjemahan oleh $\mathrm{R}$ Simatupang). Bandung: Gajah Mada University Pres.

Kirkendall, Gruber and Johson. 1987. Measurement and Evaluation for Physical Educators $2^{\text {nd }}$ ed. Champaign: Human Kinetics Publishers,Inc.

Lankor. 2007. Teori Kepelatihan Dasar: Materi Untuk Kepelatihan Tingkat Dasar. Jakarta: Kementerian Negara Pemuda dan Olahraga.
Magill A. Richard. 2001. Motor Learning: Consepts and Applications $6^{\text {th }}$ ed. New York: Mc. Graw-Hill Companies.

Pate, Russell R. Clanaghan. Bruce Mc \& Rotella Robert. 1993. Dasar-Dasar Ilmiah Kepelatihan. Semarang: IKIP Semarang Press.

Sarumpet, A. Parno \& Zulfar Djaset.1992. Permainan Besar. Jakarta : Depdikbud, Dirjen Dikti.

Schmidt, Richard A.1988. Motor Learning and Control: A Behavioral Emphasis. Champaign, Illinois: Human Kinetics Publisher, inc.

Surakhmad, Winarno.1994. Pengantar Interaksi Mengajar Belajar, Dasar dan Teknik Metodologi Pengajaran. Bandung: Tarsito.

Wina Sanjaya. 2008. Strategi Pembelajaran Berorientasi Proses Pendidikan. Jakarta: Prenada Media.

Yusuf Hadisasmita \& Aip Syarifudin. 1996 : IImu Kepelatihan Dasar. Jakarta: Dep.dikbud Dirjendikti. Proyek Pendidikan Tenaga Akademik. 